\title{
Mítico Manet. Ideologías estéticas en los orígenes de la pintura moderna
}

\author{
PUELLES ROMERO, Luis \\ Abada Editores, Madrid, 2019
}

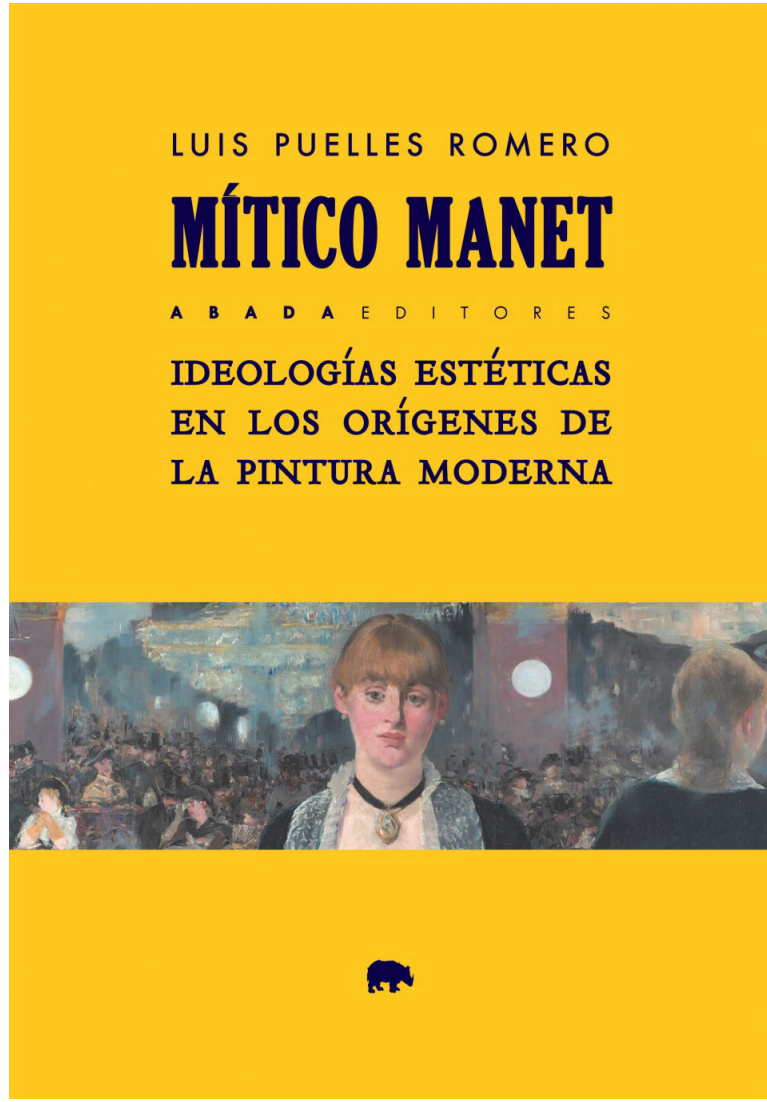

En este ejemplar, editado por Abada, Luis Puelles se pregunta por aquellos valores estéticos capaces de propiciar la consagración de Manet como «inventor de lo moderno". Será a través del diálogo con teóricos de la altura de Bataille, Foucault y Bourdieu, entre desbrozar el porqué de que Manet sea el mito fundacional de la pintura moderna. A partir de esos matices, el autor está en condiciones de arribar de manera limpia a la cuestión principal, comprendida y desarrollada a lo largo de tres episodios secuenciales que abarcan un lapso comprendido desde 1869 hasta 1884.

Antes de continuar perfilando el contenido de este ensayo creo pertinente poner de relieve la idoneidad de su au- tor para abordar este estudio. Luis Puelles Romero, profesor titular de Estética y Teoría de las Artes de la Universidad de Málaga, en su trayectoria ensayística ya ha tenido ocasión de conocer de cerca al pintor, al estar a cargo de la edición castellana de los Escritos sobre Manet de Émile Zola (2010). Es también autor de Mirar al que mira. Teoría estética y sujeto espectador (2011) y, además, de Imágenes sin mundo. Modernidad y extrañamiento (2017), obra en la que realizó su autor un sesudo estudio filosófico sobre el estatuto de la «imagen-fantasma» en el que tuvimos ocasión de advertir la presencia de Ingres, Goya y, por supuesto, Manet.

En Mítico Manet, lo decíamos antes, se rastrea el modo en el que ha ido gestándose una ideología de valores estéticos en torno al autor de Olympia, fenómeno que conlleva la glorificación de Manet y el recibimiento de sus obras como productos inequívocamente modernos. La responsabilidad de este hecho, a juicio de Puelles, recae principalmente sobre una tríada de teóricos: Baudelaire, Zola y Mallarmé. Ellos tres compartieron momentos decisivos de la vida del pintor, prestándole compañía y apoyo en los desvelos, descréditos, incertidumbres y mofas que marcaron su existencia. Por esta razón, será sirviéndose del testigo de los teóricos anunciados como Puelles dilucide su propósito, centrando su interés en tres ideas concretas que orientarán su cometido y de las que se ocupará en cada una de las secuencias que ordenan el ensayo: modernidad, originalidad y visualidad.

La primera secuencia (1859-1867) nos descubre la modernidad de Manet a través de su actitud. Actitud que le lleva a valerse de renovados modos y motivos en lo relativo a la pintura y, de igual forma, a un ahínco exacerbado por extraer cuanto de fugaz y transitorio posee la realidad. Manet sufrió abundantes desencantos, sin embargo, no cesó de transgredir y desobedecer la norma en la elaboración de su arte: cansado de reproducir lo que ya existía, Manet repudió el género histórico lanzándose a crear lo otro, tornándose apreciable en sus creaciones la franqueza de un artista que no elude lo feo ni lo mórbido, a pesar de que tal cosa pudie- 
ra provocar el rechazo de sus trabajos. Inicia así su pintura una revolución, una ruptura, aún no del todo definida, como tampoco considerada por sus contemporáneos.

En la segunda secuencia (1866-1884) tendremos ocasión de apreciar el cada vez más evidente alejamiento de la norma de las obras manetianas. El carácter singular de su mirada es advertido elocuentemente por Zola. Manet trata de diferenciarse, en un movimiento de irrenunciable posesión de sí, fenómeno que le condenará a la soledad de su talento. Será el novelista quien incansablemente nos inste a ver en Manet al «maestro del mañana», según él mismo estima. Quien, en otros términos, nos descubra la genialidad del pintor a través de una inestimable defensa pública. Escribe Puelles a este respecto: «La escritura de Zola está poseída por un furor premonitorio, por el entusiasmo y la excitación de quien cree ver el primero".

Crear, como sabemos, no conjuga necesariamente con gustar. Será esta la razón que nos guíe hacia la tercera y última secuencia (1873-1883) en la que, siguiendo a Mallarmé, observaremos la vigilancia de un jurado cada vez más obsoleto, empeñado en calificar de imperfección la grandeza del artista. Es así su labor una aventura críptica en la que la reconocibilidad queda fuera de lugar, la cual ha de ser juzgada por críticos que se muestran incapaces de ocupar el punto de vista necesario frente a unas pinturas que ganan en visualidad a la par que pierden en legibilidad: que comienzan a ser más imagen que signo. Críticos que lo ven todo lamentándose de no entender nada y, en fin, no consiguen valorar adecuadamente la combinación entre imaginación, percepción y sugerencia que Manet imprime con esmero en sus cuadros.

Agota sus esfuerzos en la búsqueda de la verdad solo suya a través de sus creaciones, en una "voluntad incansable de ser aceptado sin traicionarse», la cual canaliza a través de una fuerte "persistencia en la imposición de su mirada solo suya», en palabras del autor. Esas producciones crípticas, cada vez más visibles y menos inteligibles, extenderán su influencia hacia nuestros días. De ello se ocupa Puelles en la Coda de Mítico Manet, recobrando el motivo del Sofista platónico, la lectura que de él nos ofrece Gilles Deleuze y por supuesto el irremediable destino de la «imagen-fantasma» en el arte moderno, donde la sofisticación de Jeff Wall nos tomará como rehenes: «Manet y Wall capturan nuestra mirada, de la que se alimenta el simulacro sin dejarse atrapar, fascinándonos».

\section{Cristóbal Javier Rojas Gil Universidad de Málaga}

